Editor's Note: These short reviews of recent JNeurosci articles, written exclusively by students or postdoctoral fellows, summarize the important findings of the paper and provide additional insight and commentary. If the authors of the highlighted article have written a response to the Journal Club, the response can be found by viewing the Journal Club at www.jneurosci.org. For more information on the format, review process, and purpose of Journal Club articles, please see http://jneurosci.org/content/ preparing-manuscript\#journalclub.

\title{
Unique Maturation Trajectories of Basket and Chandelier Cells in the Neocortex
}

\author{
DSrikanth Ramaswamy \\ Blue Brain Project, Ecole Polytechnique Fédérale de Lausanne, Biotech Campus, CH 1202, Geneva, Switzerland \\ Review of Miyamae et al.
}

In the mature brain, a small but diverse group of inhibitory neurons controls the output of an overwhelming majority of excitatory neurons. Within this diverse group, parvalbumin-expressing $\left(\mathrm{PV}^{+}\right)$ neurons form the dominant inhibitory system (Rudy et al., 2011). In most brain regions, including the neocortex, $\mathrm{PV}^{+}$ neurons comprise basket cells (BCs) and chandelier cells (ChCs). BCs selectively innervate the perisomatic region of target cells to bring about fast and powerful inhibition and, thus, influence cortical function and dysfunction (Kawaguchi and Kubota, 1997; Markram et al., 2004). For example, BCs provide feedforward inhibition in the neocortex, maintain highfrequency cortical oscillations (Pouille and Scanziani, 2001; Bartos et al., 2007; Cardin et al., 2009), and are implicated in cognitive diseases, such as schizophrenia (Lewis et al., 2005; Gonzalez-Burgos and Lewis, 2008). ChCs have an exquisite axonal morphology that enables them to synapse specifically on to the axon initial segment of target cells and strategically control spiking activity (Somogyi et al.,

Received July 10, 2017; revised Sept. 14, 2017; accepted Sept. 18, 2017.

S.R. is supported by funding from the ETH domain to the Blue Brain Project, EPFL, Switzerland.

The author declares no competing financial interests.

Correspondence should be addressed to Dr. Srikanth Ramaswamy, Blue Brain Project, Ecole Polytechnique Fédérale de Lausanne, Campus Biotech, Chemin des Mines 9, CH 1202, Geneva, Switzerland. E-mail: srikanth.ramaswamy@epfl.ch.

DOI:10.1523/JNEUROSCI.1949-17.2017

Copyright $\odot 2017$ the authors $\quad 0270-6474 / 17 / 3710255-03 \$ 15.00 / 0$
1982). It is thought that the malfunction of ChCs can trigger temporal lobe epilepsy (DeFelipe, 1999; Zhu et al., 2004).

The varied but pivotal roles played by $\mathrm{BCs}$ and ChCs in cortical function suggest that the rate at which they develop morphologically and physiologically is fundamental in the emergence of cognitive skills and abilities. Although previous studies have attempted to characterize the developmental time course of $\mathrm{PV}^{+}$neurons in the cortex, they have exclusively focused either on BCs or ChCs, never examining both together (Wang et al., 2002; Okaty et al., 2009; Taniguchi et al., 2013). Therefore, an important question is the following: how do BCs and ChCs mature relative to each other to shape cognitive function? To fill this knowledge gap, Miyamae et al. (2017) assessed the morphological and physiological development of BCs and ChCs between postnatal day 8 (P8) and P73 using acute slices obtained from the prefrontal cortex (PFC) of transgenic mice expressing green fluorescent protein exclusively in $\mathrm{PV}^{+}$neurons.

Miyamae et al. (2017) discovered that, between $\sim \mathrm{P} 12$, before the onset of puberty, and $\sim$ P73, by young adulthood, BCs were found throughout layers 2-5 (L3/5; note that $\mathrm{L} 4$ is absent in mouse PFC), whereas ChCs were mostly restricted to L1/L2. The authors then asked how the morphologies of BCs and ChCs, which innervate distinct domains of their target cells, develop relative to each other.
At P8, BCs in L1/L2 showed basket-like axonal arbors extending horizontally, whereas L1/L2 ChCs had ascending candlestick-like axons but lacked their hallmark axon cartridges. Axons in L1/L2 BCs and ChCs were fully formed by P28. Dendrites of L1/L2 BCs and ChCs were mature between $\mathrm{P} 12$ and $\mathrm{P} 15$, and those of L3/5 BCs had developed by P28.

Previous work has shown that the maturation of excitatory synaptic drive influences signaling mechanisms in BCs and ChCs (Hu et al., 2014). Therefore, in the next set of experiments, Miyamae et al. (2017) looked at how the amplitude and frequency of spontaneous EPSCs (sEPSCs) in these cells changed over time. At P12, sEPSCs in L1/L2 BCs and ChCs were similar in amplitude and frequency. However, by P30, the amplitude of sEPSCs did not change in L1/L2 BCs and ChCs, whereas their frequency was significantly higher in L1/L2 BCs, indicating markedly different timescales in their synaptic maturation. Miyamae et al. (2017) conjectured that the age-related increase in sEPSC frequency in L1/L2 BCs could be due to a higher release probability of glutamate. They investigated whether the release probability of glutamate in L1/L2 BCs increased with age by measuring the shortterm depression of EPSCs. The authors found that the magnitude of synaptic depression did not increase with age in L1/L2 BCs, indicating that the release probability of glutamate was not age- 
dependent. Miyamae et al. (2017) also compared the maturation of sEPSC amplitude and frequency in L3/5 BCs and L1/L2 BCs. They observed that, at P12, the amplitude of sEPSCs was similar in L3/5 BCs and L1/L2 BCs, but the frequency in $\mathrm{L} 3 / 5$ BCs was $\sim 66 \%$ higher than that in L1/L2 BCs, suggesting that excitatory synaptic drive matures earlier in L3/5 BCs than in L1/L2 BCs. By P30, the amplitude of sEPSCs was similar between these cells, but the frequency remained higher in L3/5 BCs compared with L1/L2 BCs.

The results presented by Miyamae et al. (2017) on the absence of age-related changes in short-term depression complement previous findings on the maturation of synaptic physiology in neocortical pyramidal cells (Zhang, 2004). The shortterm dynamics of synaptic connections between neocortical pyramidal cells has been shown to be age-dependentsynapses are strongly depressing at puberty (P12) but they gradually transition to being facilitating during adulthood ( P50) (Etherington and Williams, 2011; Ramaswamy and Markram, 2015). Interestingly, Miyamae et al. (2017) found that the short-term dynamics of excitatory synapses onto L1/L2 BCs and ChCs remained robustly depressing from puberty to adulthood. For a train of incoming stimuli, depressing synapses show the strongest response to the first input, followed by an exponential decrease in response strength and reliability for subsequent inputs (Abbott et al., 1997). Therefore, preserving short-term depression of synaptic input on to L1/L2 BCs and ChCs throughout development could provide these cells with the excitatory drive required to elicit the strongest response to the first input, and reliably inhibit neighboring neurons.

Miyamae et al. (2017) characterized the development of synaptic physiology in BCs and ChCs by performing experiments in cortical slices in vitro where the level of $\mathrm{Ca}^{2+}$ in the extracellular ionic composition is typically high $(\sim 2 \mathrm{~mm})$. However, extracellular $\mathrm{Ca}^{2+}$ in the intact cortex in vivo is significantly lower $(\sim 1.2$ $\mathrm{mm}$ ). Extracellular $\mathrm{Ca}^{2+}$ levels can strongly modulate neurotransmitter release probability and, consequently, cortical activity (Borst, 2010). In addition, cortical state in vivo is regulated by numerous neuromodulators, including acetylcholine, dopamine, and noradrenaline, among many others (Harris and Thiele, 2011; Zagha and McCormick, 2014). Therefore, it would be important for future work to investigate the effects of low $\mathrm{Ca}^{2+}$ levels and different neuromodulators on the maturation of synaptic properties in $\mathrm{BCs}$ and ChCs under experimental conditions that more closely mimic the extracellular ionic composition and cortical state in vivo.

BCs and ChCs not only have conspicuous morphologies but also show a prominent fast-spiking pattern of activity (Kawaguchi and Kubota, 1997). Given that the morphological development of BCs and $\mathrm{ChCs}$ follows distinct time scales, how do their physiological properties compare over this developmental period? In a final set of experiments, Miyamae et al. (2017) catalogued age-related changes of several electrophysiological variables contributing to the fast-spiking phenotype. The authors compared the maturation of fastspiking properties in L1/L2 BCs and ChCs and found that they were underdeveloped at P12 and fully developed at P30. Four of the 10 electrophysiological variables measured by the authors (the spike half-width and threshold for initiation, membrane time-constant, and the frequency-current response) matured more slowly in L1/L2 ChCs than in L1/L2 BCs. Comparison of the developmental time course of the same four variables from puberty to adulthood in L1/L2 and L3/5 BCs revealed that fastspiking features matured at similar rates between the two populations, however, commencing earlier in L3/5 BCs.

It is thought that fast-spiking activity in BCs and ChCs enables frequency tuning and synchrony of network oscillations in the gamma band $(30-100 \mathrm{~Hz}$ ) (Bartos et al., 2007). Gamma oscillations have been proposed to regulate higher brain functions, such as visual attention, memory formation, and sensory processing (Buzsáki and Wang, 2012). In the cortex, low-frequency asynchronous gamma activity appears around P8, which develops to high-frequency synchronous activity by P20 (Doischer et al., 2008). The development of the fast-spiking phenotype in BCs and $\mathrm{ChCs}$ could influence the maturation of gamma oscillations. For example, at $\mathrm{P} 12$, the frequency-current response in L1/L2 BCs develops faster than in ChCs. This implies that, for a given amount of stimulus current, spiking activity is higher in BCs than in ChCs. Therefore, differential development of fast-spiking features could enable BCs to generate high-frequency synchronous gamma activity, whereas ChCs could influence low-frequency asynchronous oscillations. Importantly, the findings by Miyamae et al. (2017) on the later time course of physiological maturation of ChCs versus BCs is consistent with a recent study identifying delayed maturation of synaptic output in ChCs compared to BCs (Rinetti-Vargas et al., 2017). Miyamae et al. (2017) provide a framework to link developmental changes in the morphological and physiological properties of BCs and ChCs to higherorder cortical function.

\section{References}

Abbott LF, Varela JA, Sen K, Nelson SB (1997) Synaptic depression and cortical gain control. Science 275:221-224. CrossRef Medline

Bartos M, Vida I, Jonas P (2007) Synaptic mechanisms of synchronized gamma oscillations in inhibitory interneuron networks. Nat Rev Neurosci 8:45-56. CrossRef Medline

Borst JG (2010) The low synaptic release probability in vivo. Trends Neurosci 33:259-266. CrossRef Medline

Buzsáki G, Wang XJ (2012) Mechanisms of gamma oscillations. Annu Rev Neurosci 35: 203-225. CrossRef Medline

Cardin JA, Carlén M, Meletis K, Knoblich U, Zhang F, Deisseroth K, Tsai LH, Moore CI (2009) Driving fast-spiking cells induces gamma rhythm and controls sensory responses. Nature 459:663-667. CrossRef Medline

DeFelipe J (1999) Chandelier cells and epilepsy. Brain 122:1807-1822. CrossRef Medline

Doischer D, Hosp JA, Yanagawa Y, Obata K, Jonas P, Vida I, Bartos M (2008) Postnatal differentiation of basket cells from slow to fast signaling devices. J Neurosci 28:12956-12968. CrossRef Medline

Etherington SJ, Williams SR (2011) Postnatal development of intrinsic and synaptic properties transforms signaling in the layer 5 excitatory neural network of the visual cortex. J Neurosci 31:9526-9537. CrossRef Medline

Gonzalez-Burgos G, Lewis DA (2008) GABA neurons and the mechanisms of network oscillations: implications for understanding cortical dysfunction in schizophrenia. Schizophr Bull 34:944-961. CrossRef Medline

Harris KD, Thiele A (2011) Cortical state and attention. Nat Rev Neurosci 12:509-523. CrossRef Medline

Hu H, Gan J, Jonas P (2014) Fast-spiking, parvalbumin ${ }^{+}$GABAergic interneurons: from cellular design to microcircuit function. Science 345:1255263. CrossRef Medline

Kawaguchi Y, Kubota Y (1997) GABAergic cell subtypes and their synaptic connections in rat frontal cortex. Cereb Cortex 7:476-486. CrossRef Medline

Lewis DA, Hashimoto T, Volk DW (2005) Cortical inhibitory neurons and schizophrenia. Nat Rev Neurosci 6:312-324. CrossRef Medline

Markram H, Toledo-Rodriguez M, Wang Y, Gupta A, Silberberg G, Wu C (2004) Interneurons of the neocortical inhibitory system. Nat Rev Neurosci 5:793-807. CrossRef Medline

Miyamae T, Chen K, Lewis DA, Gonzalez-Burgos G (2017) Distinct physiological maturation of parvalbumin-positive neuron subtypes in mouse prefrontal cortex. J Neurosci 37:48834902. CrossRef Medline

Okaty BW, Miller MN, Sugino K, Hempel CM, Nelson SB (2009) Transcriptional and elec- 
trophysiological maturation of neocortical fast-spiking GABAergic interneurons. J Neurosci 29:7040-7052. CrossRef Medline

Pouille F, Scanziani M (2001) Enforcement of temporal fidelity in pyramidal cells by somatic feed-forward inhibition. Science 293:11591163. CrossRef Medline

Ramaswamy S, Markram H (2015) Anatomy and physiology of the thick-tufted layer 5 pyramidal neuron. Front Cell Neurosci 9:233. CrossRef Medline

Rinetti-Vargas G, Phamluong K, Ron D, Bender KJ (2017) Periadolescent maturation of GABAergic hyperpolarization at the axon initial segment. Cell Rep 20:21-29. CrossRef Medline
Rudy B, Fishell G, Lee S, Hjerling-Leffler J (2011) Three groups of interneurons account for nearly $100 \%$ of neocortical GABAergic neurons. Dev Neurobiol 71:45-61. CrossRef Medline

Somogyi P, Freund TF, Cowey A (1982) The axo-axonic interneuron in the cerebral cortex of the rat, cat and monkey. Neuroscience 7:2577-2607. CrossRef Medline

Taniguchi H, Lu J, Huang ZJ (2013) The spatial and temporal origin of chandelier cells in mouse neocortex. Science 339:70-74. CrossRef Medline

Wang Y, Gupta A, Toledo-Rodriguez M, Wu CZ, Markram H (2002) Anatomical, physiological, molecular and circuit properties of nest basket cells in the developing somatosensory cortex. Cereb Cortex 12:395-410. CrossRef Medline

Zagha E, McCormick DA (2014) Neural control of brain state. Curr Opin Neurobiol 29C:178186. CrossRef Medline

Zhang ZW (2004) Maturation of layer V pyramidal neurons in the rat prefrontal cortex: intrinsic properties and synaptic function. J Neurophysiol 91:1171-1182. CrossRef Medline

Zhu Y, Stornetta RL, Zhu JJ (2004) Chandelier cells control excessive cortical excitation: characteristics of whisker-evoked synaptic responses of layer $2 / 3$ nonpyramidal and pyramidal neurons. J Neurosci 24:5101-5108. CrossRef Medline 